\title{
Effect of toxoplasmosis on personality profiles of Iranian men and women
}

AUTHORS:

Shahram Khademvatan ${ }^{1}$

Niloufar Khajeddin²

Jasem Saki

Sakineh Izadi-Mazidi ${ }^{3}$

\section{AFFILIATIONS:}

'Department of Medical

Parasitology, Cellular and

Molecular Research Center,

Jundishapur University of

Medical Sciences, Ahvaz, Iran

2Department of Psychiatry,

Jundishapur University of

Medical Sciences, Ahvaz, Iran

3Department of Psychology,

Shahid Chamran University,

Ahvaz, Iran

CORRESPONDENCE TO:

Shahram Khademvatan

\section{EMAIL:}

Khademvatan@yahoo.com

\section{POSTAL ADDRESS:}

Department of Medical

Parasitology, Jundishapur

University of Medical Sciences,

PO Box 613715794, Ahvaz, Iran

\section{DATES:}

Received: 25 May 2012

Revised: 13 Sep. 2012

Accepted: 14 Sep. 2012

\section{KEYWORDS:}

Toxoplasma gondii; personality characteristics; Cattell's 16PF questionnaire; ELISA; Iran

\section{HOW TO CITE:}

Khademvatan S, Khajeddin N, Saki J, Izadi-Mazidi S.

Effect of toxoplasmosis on personality profiles of Iranian men and women. S Afr J Sci. 2013;109(1/2), Art. \#0017, 4 pages. http://dx.doi.org/10.1590/ sajs.2013/0017

(c) 2013. The Authors.

Published under a Creative Commons Attribution Licence.
There is evidence to suggest that the protozoan Toxoplasma gondii, which causes toxoplasmosis, changes the personality of people who are infected with it. The aim of this study was to compare the personality characteristics of Iranian students with and without latent toxoplasmosis. A total of 237 students (111 men and 126 women) of Jundishapur University of Medical Sciences (Ahvaz, Iran) were tested for the presence of anti-Toxoplasma antibodies and completed demographic questionnaires and Cattell's 16 Personality Factor Questionnaire. Data were analysed using multiple univariate analyses of variance. Women with latent toxoplasmosis had a significantly different personality profile from women without toxoplasmosis, namely higher 0 (apprehension), $N$ (privateness) and $Q_{4}$ (tension) scores, and lower $Q_{1}$ (openness to change) scores. Infected men had significantly higher $L$ (vigilance, mistrust) scores compared to non-infected men. Factors $E$ (dominance) and $Q_{1}$ (openness to change) tended to be higher in infected men than non-infected men but the difference was not quite statistically significant. Our findings have, for the first time, independently confirmed that personality profile is affected by latent toxoplasmosis.

\section{Introduction}

Toxoplasmosis is a cosmopolitan zoonosis, caused by the obligate intracellular protozoan parasite Toxoplasma gondii. Toxoplasma can infect any warm-blooded vertebrate, including humans, birds, livestock and marine mammals. ${ }^{1}$ Humans are usually infected by ingesting tissue cysts present in the undercooked meat of infected livestock and birds, or by accidentally ingesting oocysts present on vegetables contaminated with cat faeces ${ }^{2}$ or in contaminated drinking water. ${ }^{3}$

Only a small percentage of exposed adult individuals develop clinical signs of the disease.,5 After a short phase of acute toxoplasmosis, the infection becomes latent and cysts form in the central nervous system and in muscle tissue. Individuals can thus be infected for life and remain asymptomatic unless immune suppression occurs. ${ }^{6,7}$

The parasite manipulates the behaviour of its intermediate host to enhance its transmission to the definitive host. ${ }^{8,9}$ Animal studies have shown specific behavioural changes in Toxoplasma-infected rodents ${ }^{8}$ : infected mice showed impaired motor performance, deficits in learning capacity and memory, higher activity levels in both novel and familiar environments, a lower ability to discriminate between familiar and novel surroundings, and longer reaction times. Similarly, infected rats had higher activity levels, lower neophobia, reduced learning capacity and reduced specific predator avoidance. ${ }^{10}$

Evidence suggests that the parasite affects the synthesis of neurotransmitters, especially dopamine, in infected individuals which could lead to personality changes like a decrease in novelty seeking and its subscales (impulsiveness, extravagance and disorderliness). ${ }^{11}$ Moreover, changes in some factors measured by Cattell's 16 Personality Factor (16PF) Questionnaire, such as higher intelligence (B), guilt proneness (0), ergic tension $\left(Q_{4}\right)$ and radicalism $\left(Q_{1}\right)$, have been observed in Toxoplasma-infected women. ${ }^{12}$

Interestingly, gender differences in personality traits such as warmth $(A)$, rule consciousness $(G)$, vigilance or mistrust $(\mathrm{L})$, and self-control and self-image $\left(Q_{3}\right)$ have been seen in infected individuals. Toxoplasma-positive men showed lower scores in rule consciousness $(G)$ and higher scores in vigilance, mistrust and jealousy $(\mathrm{L})$ than non-infected men; whereas Toxoplasma-positive women showed higher scores in warmth (A) and lower scores in vigilance, mistrust and jealousy $(\mathrm{L})$ than non-infected women. ${ }^{13,14}$ In addition, Lindová et al. ${ }^{15}$ found that infected men scored significantly lower than non-infected men and infected women scored non-significantly higher than non-infected women in 'self-control' and 'clothes tidiness' (analogous to the 16PF factors self-control $\left(Q_{3}\right)$ and conscientiousness $(G))$. Decreased psychomotor performance has also been observed in individuals with latent toxoplasmosis. ${ }^{12}$

Approximately $50 \%$ of the Iranian population has been exposed to $T$. gondii and toxoplasmosis continues to be a public health problem in Iran. ${ }^{16}$ The possible consequences of this infection should therefore be seriously considered. Until now, all such studies have been published by one research group and conducted on Czech individuals (students, blood donors and soldiers). The purpose of this study was, therefore, to compare the personality characteristics of Iranian students with and without latent toxoplasmosis.

\section{Materials and methods}

\section{Subjects}

A total of 250 students of Jundishapur University of Medical Sciences voluntarily participated in the study and gave informed consent. The study was approved by the ethical committee of the university (No: ETH-160). A 5-mL blood sample was taken from each subject for serological analysis. Each subject was also asked to complete the Persian version of Cattell's 16PF Questionnaire as well as a questionnaire to obtain demographic data about ethnicity, gender, age, level of education, marital status and employment. Of the 250 volunteers, 13 gave 
incomplete questionnaires and were excluded. The study was therefore conducted on 237 students (111 men and 126 women) with a mean age of 24.9 years ( $S D=4.57$ years). Data were collected over a period of 12 months from 2010 to 2011. Personality assessments were conducted by a psychologist and a psychiatrist.

\section{Questionnaires}

Cattell's 16PF Questionnaire consists of 187 items. For each question, participants have to choose between three answers, generally "yes", "no" or "?". The 16PF measures 16 primary factors: warmth $(A)$, reasoning $(B)$, emotional stability $(C)$, dominance $(E)$, liveliness $(F)$, rule consciousness $(G)$, social boldness $(H)$, sensitivity $(I)$, vigilance $(L)$, abstractedness $(\mathrm{M})$, privateness $(\mathrm{N})$, apprehension $(0)$, openness to change $\left(Q_{1}\right)$, self-reliance $\left(Q_{2}\right)$, perfectionism $\left(Q_{3}\right)$ and tension $\left(Q_{4}\right) .{ }^{17}$

The range of the test-retest reliability coefficient is reported to be from 0.58 to 0.88 , with a 2 -month interval between tests. ${ }^{18} \mathrm{~A}$ construct validity of the questionnaire has shown that it measures 16 distinct personality traits. ${ }^{19} \mathrm{~A}$ factor analytic construction of the test has also been performed and supports its validity. ${ }^{18}$ The Cattell's 16PF Questionnaire has been shown to be reliable and valid in an Iranian population. ${ }^{20}$

\section{Serological test for toxoplasmosis}

In order to identify Toxoplasma IgG and IgM, $5 \mathrm{~mL}$ of blood was taken for serological assessment. After centrifugation, samples were kept at $-20^{\circ} \mathrm{C}$ until processed. Specific anti-Toxoplasma IgG and IgM antibody concentrations were determined by enzyme-linked immunosorbent assays (IgG and IgM, Trinity Biotech Captia ${ }^{\mathrm{TM}}$, Jamestown, NY, USA) according to the manufacturer's instructions.

\section{Statistical tests}

Data were analysed using multiple univariate analyses of variance (ANOVAs), the Chi-square test and Fisher's exact test. The probability level of 0.05 was accepted as statistically significant. Statistical analyses were carried out using SPSS version 16.

\section{Results}

Serological analyses confirmed that 58 men $(24.6 \%)$ and 54 women (22.9\%) were sero-positive and 53 men (22.5\%) and 72 women (30.1\%) were sero-negative for Toxoplasma antibodies.

Frequencies of the participants' demographic features and the distribution of latent toxoplasmosis according to the demographic characteristics are listed in Table 1. There were no differences in prevalence of toxoplasmosis based on sex, marital status, employment, level of education or ethnicity (all $p>0.05$; Table 1 ).

There was also no difference in sero-positivity between married and single women (Table 2).

The personality characteristics of infected and non-infected subjects were compared using multiple univariate ANOVAs. There were significant differences between infected and non-infected women in factors 0 (apprehension) ( $F=5.10, p=0.02), Q 4$ (tension) $(F=7.00, p=0.009$ ), Q1 (openness to change) ( $F=6.44, p=0.01$ ) and $N$ (privateness) $(F=8.31, p=0.005)$. A comparison of all 16 traits is shown in Table 3 .

There was a significant difference between infected and non-infected men in factor $L$ (vigilance, mistrust) $(F=4.57, p=0.03)$. Differences in factor $E$ (dominance) $(F=3.39, p=0.06)$ and $Q 1$ (openness to change) $(F=3.44, p=0.06)$ were not quite significant at $p<0.05$. A comparison of all 16 traits is shown in Table 4 .

\section{Discussion and conclusion}

Personality changes caused by latent toxoplasmosis have been the subject of recent debate and a few studies, mainly on Czech individuals, have been conducted in this regard. The present study was the first to investigate the matter in another population - Iranians. The personality profiles of Iranian men and women with latent toxoplasmosis differed from those of their sero-negative counterparts; our findings are consistent with those of previous studies. ${ }^{12-14}$ Flegr and Havlícek ${ }^{12}$ reported that $T$. gondii changes some of the dimensions measured by Cattell's 16PF Questionnaire directly, whereas others are changed because of their correlation with the factors that are influenced by the parasite. ${ }^{12}$ It has also been noted that latent toxoplasmosis can alter aggregate personality at the population level by effects on individual personality; the average personality of a population may be changed if most of the individuals are infected with $T$. gondiii. ${ }^{21}$ Prevalence levels of this parasite vary widely among human populations, because of differences in culture (such as eating habits, food preparation, the keeping of cats and other pets), climate, hygiene, working with soil and so on. Therefore aggregate personality could vary among populations because of their various seroprevalence of $T$. gondii. ${ }^{21}$ The differences in results among studies which have been done in various populations could be partially explained by the relationship between the prevalence of toxoplasmosis and aggregate personality.

Table 1: Distribution of latent toxoplasmosis according to demographic variable

\begin{tabular}{|c|c|c|c|c|c|}
\hline \multicolumn{2}{|c|}{$\begin{array}{l}\text { Demographic } \\
\text { variable }\end{array}$} & \multicolumn{3}{|c|}{ Frequency N (\%) } & \multirow[t]{2}{*}{$p$-value } \\
\hline & & \multirow{2}{*}{$\begin{array}{l}\text { Total } \\
126(53.2 \%)\end{array}$} & \multirow{2}{*}{$\begin{array}{l}\text { IgG- } \\
\text { positive } \\
54(42.9 \%)\end{array}$} & \multirow{2}{*}{$\begin{array}{l}\text { IgG- } \\
\text { negative } \\
72(57.1 \%)\end{array}$} & \\
\hline Sex & Women & & & & \multirow{2}{*}{0.1} \\
\hline & Men & $111(46.8 \%)$ & $58(52.3 \%)$ & $53(47.7 \%)$ & \\
\hline \multirow{3}{*}{$\begin{array}{l}\text { Marital } \\
\text { status }\end{array}$} & Single & $179(75.5 \%)$ & $87(48.6 \%)$ & $92(51.4 \%)$ & \multirow{3}{*}{0.5} \\
\hline & Married & $58(24.5 \%)$ & $25(43.1 \%)$ & $33(56.8 \%)$ & \\
\hline & $\begin{array}{l}\text { Divorced/ } \\
\text { widowed }\end{array}$ & 0 & 0 & 0 & \\
\hline \multirow[t]{2}{*}{ Employed } & Yes & $65(27.4 \%)$ & $33(50.8 \%)$ & $32(49.2 \%)$ & \multirow[t]{2}{*}{0.5} \\
\hline & No & $172(71.6 \%)$ & $79(44.1 \%)$ & $93(54.1 \%)$ & \\
\hline \multirow{4}{*}{$\begin{array}{l}\text { Level of } \\
\text { education }\end{array}$} & Diploma & $26(11 \%)$ & $14(53.8)$ & $12(46.2 \%)$ & \multirow{4}{*}{0.4} \\
\hline & $\begin{array}{l}\text { Associate } \\
\text { Degree }\end{array}$ & 42 (17.7\%) & $21(50 \%)$ & $21(50 \%)$ & \\
\hline & Bachelor & $141(59.5 \%)$ & $63(44.7 \%)$ & $78(55.3 \%)$ & \\
\hline & $\begin{array}{l}\text { Post- } \\
\text { graduate }\end{array}$ & 28 (11.8\%) & $14(50 \%)$ & $14(50 \%)$ & \\
\hline \multirow[t]{6}{*}{ Ethnicity } & Fars & $80(33.8 \%)$ & $33(41.3 \%)$ & $47(58.8 \%)$ & \multirow{6}{*}{0.3} \\
\hline & Arab & $59(24.9 \%)$ & $25(42.4 \%)$ & $34(57.6 \%)$ & \\
\hline & Lor & $53(22.4 \%)$ & $29(54.7 \%)$ & $24(45.3 \%)$ & \\
\hline & Kord & $18(7.6 \%)$ & $10(55.5 \%)$ & $8(44.4)$ & \\
\hline & Turk & $12(5.1 \%)$ & $5(41.6 \%)$ & $7(58.3 \%)$ & \\
\hline & Other & $15(6.3 \%)$ & $10(66.6 \%)$ & $5(33.3 \%)$ & \\
\hline
\end{tabular}

According to manipulation hypothesis, changes in human personality can be a product of the manipulation activity of $T$. gondii. These changes may enhance the transmission of the parasite from the intermediate to the definitive host in order to complete the parasite's life cycle. ${ }^{22}$ However, it is also possible that neuropathological or neuroimmunological effects of the parasite cause the changes and not the manipulation activity of the parasite. ${ }^{23} T$. gondii increases dopamine in rodents. The behaviour of infected and non-infected rodents changed differentially after treatment 
with a selective dopamine uptake inhibitor. ${ }^{23}$ Moreover, high dopamine levels would be expected to cause low levels of novelty seeking among infected humans. ${ }^{11}$ Dopamine plays an important role in the control of movement, reward to stimuli, pleasure, dependency, motivation and cognition, and in species-specific and stimuli-specific fear. ${ }^{22}$

Table 2: Comparison of the seroprevalence of anti-Toxoplasma IgG antibodies in single and married women

\begin{tabular}{l|c|c|c}
\hline \hline \multirow{2}{*}{ Serological result } & \multicolumn{2}{|l|}{ Frequency N (\%) } & \multirow{2}{*}{-value } \\
\cline { 2 - 3 } & Single women & Married women & \\
\hline \hline IgG-positive & $42(43.8 \%)$ & $10(35.7 \%)$ & \multirow{2}{*}{0.5} \\
\hline IgG-negative & $54(56.3 \%)$ & $18(64.3 \%)$ & \\
\hline Total & 96 & 28 & \\
\hline
\end{tabular}

Table 3: Comparison using multiple univariate ANOVA of personality characteristics in women according to seroprevalence

\begin{tabular}{|c|c|c|c|c|c|c|}
\hline \multirow[t]{2}{*}{$\begin{array}{l}\text { Personality } \\
\text { characteristic }\end{array}$} & \multicolumn{2}{|c|}{$\begin{array}{l}\text { IgG-positive } \\
\text { women }\end{array}$} & \multicolumn{2}{|c|}{$\begin{array}{l}\text { IgG-negative } \\
\text { women }\end{array}$} & \multirow{2}{*}{$F_{1,124}$} & \multirow{2}{*}{$p$-value } \\
\hline & Mean & SD & Mean & SD & & \\
\hline Reasoning (B) & 6.00 & 2.62 & 6.05 & 2.50 & 0.01 & 0.90 \\
\hline Perfectionism $\left(Q_{3}\right)$ & 13.85 & 1.90 & 13.53 & 3.27 & 0.40 & 0.50 \\
\hline Tension $\left(Q_{4}\right)$ & 13.33 & 3.96 & 11.57 & 3.37 & 7.10 & 0.009 \\
\hline Vigilance (L) & 10.27 & 2.77 & 9.77 & 2.61 & 1.07 & 0.30 \\
\hline Warmth (A) & 9.37 & 3.57 & 8.83 & 2.95 & 0.85 & 0.35 \\
\hline $\begin{array}{l}\text { Rule } \\
\text { consciousness } \\
\text { (G) }\end{array}$ & 13.03 & 2.20 & 13.11 & 2.69 & 0.02 & 0.86 \\
\hline Self-reliance $\left(Q_{2}\right)$ & 8.64 & 3.23 & 9.01 & 3.02 & 0.42 & 0.51 \\
\hline Privateness (N) & 10.24 & 2.33 & 8.94 & 2.55 & 8.51 & 0.004 \\
\hline $\begin{array}{l}\text { Abstractedness } \\
\text { (M) }\end{array}$ & 9.40 & 3.68 & 10.32 & 3.60 & 1.94 & 0.16 \\
\hline Liveliness (F) & 12.68 & 2.73 & 13.15 & 3.03 & 0.80 & 0.37 \\
\hline Sensitivity (I) & 8.51 & 2.56 & 8.45 & 2.86 & 0.02 & 0.89 \\
\hline $\begin{array}{l}\text { Social boldness } \\
\text { (H) }\end{array}$ & 13.37 & 3.95 & 14.43 & 3.79 & 2.33 & 0.13 \\
\hline $\begin{array}{l}\text { Emotional stability } \\
\text { (C) }\end{array}$ & 11.62 & 3.21 & 12.02 & 3.19 & 0.47 & 0.49 \\
\hline Dominance $(\mathrm{E})$ & 11.05 & 2.65 & 11.30 & 2.67 & 0.27 & 0.59 \\
\hline Apprehension (0) & 9.85 & 3.66 & 8.47 & 3.00 & 5.28 & 0.02 \\
\hline $\begin{array}{l}\text { Openness to } \\
\text { change }\left(Q_{1}\right)\end{array}$ & 8.50 & 2.08 & 9.60 & 2.59 & 6.58 & 0.01 \\
\hline
\end{tabular}

There were significant differences in personality profiles between infected individuals and their non-infected counterparts in this study. Toxoplasma-positive women had significantly higher scores in guilt proneness $(0)$, ergic tension $\left(Q_{4}\right)$ and privateness $(\mathrm{N})$ than Toxoplasmanegative women. Infected men scored higher in factor $L$ (vigilance, suspecting, jealous and dogmatic) than non-infected men. In contrast with previous studies, we did not find differences between infected and non-infected subjects with respect to warmth $(A)$, rule consciousness $(\mathrm{G})$ or self-control $\left(Q_{3}\right)$. Our findings indicate that Toxoplasma-positive women scored lower than the sero-negative women in radicalism $\left(Q_{1}\right)$, whereas the reverse pattern was shown in men. In the present study, men with latent toxoplasmosis had higher scores in factor $\mathrm{E}$ (dominance) than the sero-negative men. Sex-determined changes in the kinetics and quantities of cytokine production during Toxoplasma infection may, in part, explain sex differences in personality profile changes associated with latent chronic toxoplasmosis. ${ }^{24}$ As shown in animal studies, higher levels of interferon-gamma (IFN $\gamma$ ) are produced by the spleens of male mice than those of female mice in the early stages of Toxoplasma infection. ${ }^{25}$ Rapid response to $T$. gondii infection with high levels of IFNy and tumour necrosis factor-alpha helps male mice to control parasite multiplication. Interleukin-10 may also be of importance in downregulating the parasite. Higher cyst burdens in female mice may be caused by the inability to respond as quickly as their male counterparts in terms of IFNy production. ${ }^{25}$

Table 4: Comparison using multiple univariate ANOVA of personality characteristics in men according to seroprevalence

\begin{tabular}{|c|c|c|c|c|c|c|}
\hline \multirow[t]{2}{*}{$\begin{array}{l}\text { Personality } \\
\text { characteristic }\end{array}$} & \multicolumn{2}{|c|}{$\begin{array}{l}\text { IgG-positive } \\
\text { men }\end{array}$} & \multicolumn{2}{|c|}{$\begin{array}{l}\text { IgG-negative } \\
\text { men }\end{array}$} & \multirow{2}{*}{$F_{1,109}$} & \multirow[t]{2}{*}{$p$-value } \\
\hline & Mean & SD & Mean & SD & & \\
\hline Reasoning (B) & 6.10 & 2.76 & 5.78 & 2.60 & 1.82 & 0.17 \\
\hline Perfectionism $\left(Q_{3}\right)$ & 13.50 & 2.51 & 13.39 & 2.70 & 0.17 & 0.68 \\
\hline Tension $\left(Q_{4}\right)$ & 10.93 & 3.50 & 11.10 & 3.38 & 0.75 & 0.38 \\
\hline Vigilance (L) & 10.56 & 2.97 & 10.00 & 2.97 & 4.57 & 0.03 \\
\hline Warmth (A) & 8.39 & 2.87 & 8.54 & 2.90 & 0.28 & 0.59 \\
\hline $\begin{array}{l}\text { Rule } \\
\text { consciousness } \\
\text { (G) }\end{array}$ & 13.63 & 1.89 & 13.34 & 2.60 & 1.35 & 0.24 \\
\hline Self-reliance $\left(Q_{2}\right)$ & 8.32 & 2.96 & 8.00 & 2.70 & 1.50 & 0.20 \\
\hline Privateness (N) & 9.67 & 2.44 & 9.98 & 2.46 & 0.43 & 0.51 \\
\hline $\begin{array}{l}\text { Abstractedness } \\
\text { (M) }\end{array}$ & 10.77 & 3.11 & 11.01 & 3.06 & 0.17 & 0.67 \\
\hline Liveliness (F) & 12.34 & 2.63 & 12.84 & 3.04 & 0.75 & 0.38 \\
\hline Sensitivity (I) & 8.48 & 3.26 & 8.62 & 3.03 & 0.25 & 0.61 \\
\hline $\begin{array}{l}\text { Social } \\
\text { boldness (H) }\end{array}$ & 13.55 & 4.91 & 13.22 & 4.30 & 0.68 & 0.40 \\
\hline $\begin{array}{l}\text { Emotional stability } \\
\text { (C) }\end{array}$ & 11.22 & 3.26 & 11.56 & 3.21 & 1.30 & 0.24 \\
\hline Dominance (E) & 11.32 & 3.05 & 11.83 & 3.08 & 3.30 & 0.06 \\
\hline Apprehension (0) & 7.68 & 3.70 & 8.10 & 3.37 & 2.20 & 0.13 \\
\hline $\begin{array}{l}\text { Openness to } \\
\text { change }\left(Q_{1}\right)\end{array}$ & 9.08 & 2.33 & 8.68 & 2.44 & 3.44 & 0.06 \\
\hline
\end{tabular}

In humans, hormone levels affecting dopamine levels also are assumed to mediate the gender differences in behavioural changes induced by latent toxoplasmosis. Female hormones protect the dopaminergic system; thus infected women experience less severe, or even opposite behavioural effects compared to infected men. ${ }^{26}$ 
We found no significant difference in prevalence of $\lg G$ positivity between men and women. By contrast, Lindová et al. ${ }^{15}$ reported higher seroprevalance in male compared to female students. The opposite result, that is, a higher prevalence in men than in women, was found by Xiao et al. ${ }^{27}$

Considering that premarital sex is rare in Iran, we analysed the prevalence of toxoplasmosis among married and single women to test recent suggestions (Hari Dass et al. ${ }^{28}$ ) that toxoplasmosis can be transmitted sexually. However, we found no significant difference in prevalence between married and single women.

In conclusion, our results show that $T$. gondii infection affects human personality characteristics. Therefore, toxoplasmosis should be considered as one of the biological factors that are able to affect key traits of human personality. The main strength of the present study is that it is the first independent confirmation of results of similar studies published by a research group in Prague.

Several limitations should, however, be taken into account. The majority of subjects was highly educated, which means the findings should be generalised to other groups or those with a different level of education with caution. Cattell's 16PF Questionnaire is a self-reporting questionnaire. It is possible that participants were less than honest to appear more socially desirable; there is no definitive way to confirm the accuracy of the answers. However, assurances of anonymity and confidentiality were given to the participants before they completed the questionnaire. A self-selection bias is also possible as participation in the study was voluntary.

Because of variation in culture, hygiene and climate, among others, prevalence of $T$. gondii infection varies among human populations. ${ }^{21}$ Therefore our findings should be generalised to other cultures and populations with caution. Research on the effects of $T$. gondii infection on personality in different cultures and in other populations is recommended.

\section{Acknowledgements}

This study was financially supported by grant no. U-90026 from Jundishapur University of Medical Sciences. We appreciate the support of the staff of the Protozoology Laboratory at the Jundishapur University of Medical Sciences.

\section{Authors' contributions}

S.K. and J.S. were the project leaders and were responsible for experimental and project design and preparation of the samples. S.I-M. and N.K. were responsible for the psychological appraisal and for performing the statistical analyses and interpretation of the data. S.I-M. and S.K. drafted the manuscript and N.K. and J.S. revised it. All authors read and approved the final manuscript.

\section{References}

1. Dubey JP. Toxoplasma gondii infections in chickens (Gallus domesticus): Relevance, clinical disease, diagnosis and public health significance. Zoonoses Public Health. 2010;57(1):60-73. http://dx.doi.org/10.1111/ j.1863-2378.2009.01274.x

2. Kijlstra A, Jongert $E$. Control of the risk of human toxoplasmosis transmitted by meat. Int J Parasitol. 2008;38(12):1359-1370. http://dx. doi. org/10.1016/j.ijpara.2008.06.002.

3. Herrmann DC, Pantchev N, Vrhovec MG, et al. Toxoplasma gondii genotypes identified in 0ocysts shed by cats in Germany. Int J Parasitol. 2010;40(3):285-292. http://dx.doi.org/10.1016/j.jpara.2009.08.001

4. Montoya JG, Liesenfeld O. Toxoplasmosis. Lancet. 2004;363(9425):1965-1976. http://dx.doi.org/10.1016/S0140-6736(04)16412-X

5. López-Castillo CA, De-la-Torre A. Definition of acquired toxoplasmosis infection: When is it congenital or acquired? Arch Soc Esp Oftalmol. 2011;86(7):224-225.
6. Dubey JP, Jones JL. Toxoplasma gondii infection in humans and animals in the United States. Int J Parasitol. 2008:38(11):1257-1278. http://dx.doi. org/10.1016/j.ijpara.2008.03.007

7. Miller CM, Boulter NR, Ikin RJ, Smith NC. The immunobiology of the innate response to Toxoplasma gondii. Int J Parasitol. 2009;39(1):23-39. http:// dx.doi.org/10.1016/j.ijpara.2008.08.002

8. Webster JP. The effect of Toxoplasma gondii on animal behaviour: Playing cat and mouse. Schizophr Bull. 2007;33(3):752-756. http://dx.doi. org/10.1093/schbul/sbl073

9. Da Silva RC, Langoni H. Toxoplasma gondii: Host-parasite interaction and behaviour manipulation. Parasitol Res. 2009;105(4):893-898. http://dx.doi. org/10.1007/s00436-009-1526-6

10. Novotna M, Hanusova J, Klose J, et al. Probable neuroimmunological link between Toxoplasma and cytomegalovirus infections and personality changes in the human host. BMC Infect Dis. 2005;5:54. http://dx.doi. org/10.1186/1471-2334-5-54

11. Flegr J, Preiss M, Klose J, Havlícek J, Vitákova M, Kodym P. Decreased level of psychobiological factor novelty seeking and lower intelligence in men latently infected with the protozoan parasite Toxoplasma gondii. Dopamine, a missing link between schizophrenia and toxoplasmosis? Biol Psychol. 2003; 63:253-268. http://dx.doi.org/10.1016/S0301-0511(03)00075-9

12. Flegr J, Havlícek J. Changes in the personality profile of young women with latent toxoplasmosis. Folia Parasitol (Praha). 1999;46(1):22-28.

13. Flegr J, Zitková S, Kodym P, Frynta D. Induction of changes in human behavior by the parasitic protozoan Toxoplasma gondii. Parasitology. 1996; 113(Pt 1):49-54. http://dx.doi.org/10.1017/S0031182000066269

14. Flegr J, Kodym P, Tolarová V. Correlation of duration of latent Toxoplasma gondii infection with personality changes in women. Biol Psychol. 2000;53(1):57-68. http://dx.doi.org/10.1016/S0301-0511(00)00034-X

15. Lindová J, Novotná M, Havlíček J, Jozífk ová E, Skallová A, Kolbeková P, et al. Gender differences in behavioral changes induced by latent toxoplasmosis. Int J Parasitol. 2006;36:1485-1492. http://dx.doi.org/10.1016/j. ijpara.2006.07.008

16. Assmar M, Amirkhani A, Piazak N, Hovanesian A, Kooloobandi A, Etessami R. Toxoplasmosis in Iran. Results of a seroepidemiological study. Bull Soc Pathol Exot. 1997;90(1):19-21.

17. Rossier J, Meyer de Stadelhofen F, Berthoud S. The hierarchical structures of the NEO PI-R and the 16 PF. Eur J Psychol Assess. 2004;20:27-38. http://dx.doi.org/10.1027/1015-5759.20.1.27

18. Kruger PC. The relationship between personality and biographical factors in absenteeism [dissertation]. Pretoria: University of South Africa; 2008.

19. Conn SR, Rieke ML. The $16 \mathrm{PF}$ technical manual. $5^{\text {th }}$ ed. Champaign, IL Institute for Personality and Ability Testing; 1994.

20. Ebadi GH, Delavar A, Najarian B. Examining factor structure of Cattell's 16 Personality Factor test in Ahvaz City. J Educ Psychol. 2003;3(10):83-100.

21. Lafferty KD. Can the common brain parasite, Toxoplasma gondii, influence human culture? Proc R Soc B. 2006;273:2749-2755. http://dx.doi. org/10.1098/rspb.2006.3641

22. Prandovszky E, Gaskell E, Martin H, Dubey JP, Webster JP, McConkey GA. The neurotropic parasite Toxoplasma gondii increases dopamine metabolism. PLoS One. 2011;6(9):e23866. http://dx.doi.org/10.1371/ journal.pone.0023866

23. Flegr J. Effects of Toxoplasma on human behaviour. Schizophr Bull. 2007;33(3):757-760. http://dx.doi.org/10.1093/schbul/sbl074

24. Roberts CW, Cruickshank SM, Alexander J. Sex-determined resistance to Toxoplasma gondii is associated with temporal differences in cytokine production. Infect Immun. 1995;63(7):2549-2555.

25. Prandota J. Neuropathological changes and clinical features of autism spectrum disorder participants are similar to that reported in congenital and chronic cerebral toxoplasmosis in humans and mice. Res Autism Spectr Disord. 2011;4:103-118. http://dx.doi.org/10.1016/j.rasd.2009.09.007

26. Dunn JC, Cole EF, Quinn JL. Personality and parasites: Sex-dependent associations between avian malaria infection and multiple behavioural traits. Behav Ecol Sociobiol. 2011;65:1459-1471. http://dx.doi.org/10.1007/ s00265-011-1156-8

27. Xiao Y, Yin J, Jiang N, Xiang M, Hao L, Lu H, et al. Seroepidemiology of human Toxoplasma gondii infection in China. BMC Infect Dis. 2010;10:4.

28. Hari Dass SA, Vasudevan A, Dutta D, Soh L, Sapolsky RM, Vyas A. Protozoan parasite Toxoplasma gondii manipulates mate choice in rats by enhancing attractiveness of males. PLoS One. 2011;6(11):1-6. 